\title{
PROBLEMATIKA PEMBELAJARAN DARING DI MASA PANDEMI COVID-19 DI SMA DHARMA PRAJA DENPASAR
}

\section{Kompyang Sri Wahyuningsih}

\author{
Universitas Hindu Negeri I Gusti Bagus Sugriwa Denpasar \\ kompyangsriwahyuningsih@gmail.com
}

\begin{abstract}
Diterima tanggal 3 Januari 2021, diseleksi tanggal 1 Februari 2021, dan disetujui tanggal 2 Februari 2021
\end{abstract}

\begin{abstract}
The purpose of this study was to analyze the problems of online learning during the Covid-19 pandemic and the solutions to solve them at SMA Dharma Praja Denpasar. This type of research is a case study or field research using primary data sources obtained through direct interviews by following health protocols. In addition, data is also obtained through library research using secondary data sources collected through textbooks, e-books, laws and regulations, websites, and other sources relevant to the research problem. The research data were analyzed qualitatively with an interactive model, which consists of data collection, data reduction, data presentation, and drawing conclusions. The results of this study indicate that the implementation of online learning during the Covid19 pandemic at Dharma Praja Denpasar High School has various problems, both from teachers, students and parents of students. The problems of the teacher are in the form of weak mastery of IT and limited access to supervision of students, from students, namely lack of motivation and concentration in learning, limited support facilities, internet network access, while from parents in the form of limited time to accompany their children during online learning. These various problems can be overcome by increasing competence in the use of IT, giving simple tasks, intensive supervision by involving parents.
\end{abstract}

Keywords: Problems, Online Learning, Covid-19, Solutions

\begin{abstract}
ABSTRAK
Tujuan penelitian ini adalah untuk menganalisis problematika pembelajaran daring di masa pandemi Covid-19 dan solusi pemecahannya di SMA Dharma Praja Denpasar. Jenis penelitian ini adalah studi kasus atau penelitian lapangan dengan menggunakan sumber data primer yang didapat melalui wawancara langsung dengan mengikuti protokol kesehatan. Selain itu data juga diperoleh melalui studi kepustakaan dengan menggunakan sumber data sekunder yang dikumpulkan melalui buku teks, e-book, peraturan perundang-undangan, website, dan sumbersumber lain yang relevan dengan masalah penelitian. Data penelitian ini dianalisis secara kualitatif dengan model interaktif, yang terdiri dari pengumpulan data,
\end{abstract}


reduksi data, penyajian data, dan penarikan kesimpulan. Hasil penelitian ini menunjukkan bahwa pelaksanaan pembelajaran daring di masa pandemi Covid-19 di SMA Dharma Praja Denpasar memiliki beragam problematika baik dari guru, peserta didik dan orang tua peserta didik. Permasalahan dari guru berupa lemahnya penguasaan IT dan terbatasnya akses pengawasan terhadap peserta didik, dari peserta didik yaitu kurangnya motivasi dan konsentrasi dalam belajar, keterbatasan fasilitas pendukung, akses jaringan internet, sementara dari orang tua berupa keterbatasan waktu dalam menemani anaknya di saat pembelajaran daring. Beragam permasalahan tersebut dapat diatasi dengan meningkatkan kompetensi dalam penggunaan IT, pemberian tugas yang sederhana, pengawasan intensif dengan melibatkan orang tua.

Kata Kunci : Problematika, Pembelajaran Daring, Covid-19, Solusi

\section{PENDAHULUAN}

Wabah Covid-19 ini telah melumpuhkan seluruh sektor kehidupan tidak terkecuali di dunia pendidikan. Pembelajaran yang awalnya tatap muka secara tibatiba tidak dapat dilakukan. Covid-19 ini menular begitu cepat dan menyebar hampir ke seluruh negara termasuk Indonesia, sehingga Badan Kesehatan Dunia (WHO) menjadikan wabah ini menjadi pandemi global pada tanggal 11 maret 2020. Penyakit Corona virus 2019 (COVID-19) adalah penyakit menular yang disebabkan oleh sindrom pernapasan akut corona virus 2 (SARS-CoV-2). Penyakit ini pertama kali diidentifikasi pada Desember 2019 di Wuhan, ibukota provinsi Hubei China, dan sejak itu menyebar secara global, mengakibatkan pandemi corona virus 2019 yang sedang berlangsung hingga saat ini. Gejala umum termasuk demam ,batuk, dan sesak napas. Gejala lain mungkin termasuk nyeri otot, diare, sakit tenggorokan, kehilangan bau, dan sakit perut. Sementara sebagian besar kasus mengakibatkan gejala ringan, beberapa berkembang menjadi pneumonia virus dan kegagalan multiorgan. Pada 5 April 2020, lebih dari 1,2 juta kasus telah dilaporkan di lebih dari dua ratus Negara dan wilayah, mengakibatkan lebih dari 64.700 kematian. Lebih dari 246.000 orang telah pulih.

Manusia merupakan mahluk sosial yang memungkinkan saling berinteraksi secara langsung sehingga tingkat penyebaran pandemi Covid-19 semakin pesat. Sehingga Pemerintah tengah menyiapkan aturan karantina kewilayahan atau lockdown untuk memutuskan mata rantai penyebaran virus corona atau COVID 19. Karantina kewilayahan diatur dalam aturan undang-undang nomor 6 tahun 2018 tentang kekarantina kesehatan. Bertujuan membatasi perpindahan orang, membatasi kerumunan orang, membatasi gerakan orang demi keselamatan bersama.

Sebagian besar orang yang terinfeksi COVID 19, akan mengalami penyakit pernapasan ringan hingga sedang, bahkan menyebabkan sulit bernafas sehingga meninggal. Virus ini bisa sembuh dengan sendirinya karena imunitas tubuh. Namun orang tua lebih rentan terkena virus ini. Apalagi orang tua yang memiliki penyakit diabetes. Pernapasan kronis dan kanker. Karena adanya virus ini, aktivitas masyarakat di berbagai Negara jadi terganggu sehingga membuat masyarakat di dunia harus tetap diam dirumah untuk memutus mata rantai virus corona agar tidak semakin menyebar. Lalu perekonomian di berbagai dunia juga semakin menurun karena adanya virus ini. 
Di sektor pendidikan, pemerintah melalui Kementrian Pendidikan dan Kebudayaan (Kemendikbud) telah menerapkan kebijakan Learning From Home atau belajar dari rumah terutama bagi satuan pendidikan yang berada di wilayah zona kuning, orange, dan merah. Pada zona kuning atau disebut juga zona risiko rendah, adalah ada kasus baru tapi jumlahnya hanya sedikit. Selain itu, penularan atau transmisi juga masih ada kemungkinan bisa terjadi. Pada zona oranye, adalah jumlah kasus yang ada di wilayah tersebut sudah relatif banyak. Dalam hal transmisi atau penularannnya, zona risiko sedang ini dipastikan ada dan lebih luas dibandingkan di zona kuning sedangkan pada zona merah adalah kasus baru yang ditemukan sangat banyak melebihi yang ditemukan pada zona oranye. Dalam segi penularan atau transmisinya dipastikan meluas dengan sangat cepat dibandingkan pada zona-zona lainnya. Untuk meminimalisir penyebaran virus corona ini, maka pembelajaran di lakukan dari rumah atau learning from home.

Learning from home atau Belajar dari Rumah dilaksanakan dengan sistem Pembelajaran Jarak Jauh (PJJ). Dalam Undang-undang No. 20 tahun 2003 pasal 1 ayat 15 , dijelaskan bahwa PJJ adalah pendidikan yang peserta didiknya terpisah dari pendidik dan pembelajarannya menggunakan berbagai sumber belajar melalui teknologi komunikasi, informasi dan media lain. Dalam pelaksanaannya, PJJ dibagi menjadi dua pendekatan, yaitu pembelajaran jarak jauh dalam jaringan (daring) dan pembelajaran jarak jauh luar jaringan (luring). Dalam pelaksanaan PJJ, satuan pendidikan dapat memilih pendekatan (daring atau luring atau kombinasi keduanya) sesuai dengan karakteristik dan ketersediaan, kesiapan sarana dan prasarana.

Salah satu dari Pembelajaran Jarak Jauh (PJJ) adalah pembelajaran daring. Sistem pembelajaran daring merupakan sistem pembelajaran tanpa tatap muka secara langsung antara guru dan siswa namun menggunakan plat form atau aplikasi digital dengan menggunakan jaringan internet, seperti whatsapp, telegram, zoom meeting, google meet, google classroom, quiepper school, ruang guru dan aplikasi lainnya. Guru dan siswa melakukan pembelajaran bersama, dalam waktu yang sama, di tempat yang berbeda. Istilah pembelajaran daring dan luring muncul sebagai salah satu bentuk pola pembelajaran di era teknologi informasi seperti sekarang ini.

Daring merupakan singkatan dari "dalam jaringan" sebagai pengganti kata online yang sering kita gunakan dalam kaitannya dengan teknologi internet. Daring adalah terjemahan dari istilah online yang bermakna tersambung ke dalam jaringan internet. Pembelajaran daring artinya adalah pembelajaran yang dilakukan secara online, menggunakan aplikasi pembelajaran maupun jejaring sosial. Pembelajaran daring merupakan pembelajaran yang dilakukan tanpa melakukan tatap muka, tetapi melalui platform yang telah tersedia. Segala bentuk materi pelajaran didistribusikan secara online, komunikasi juga dilakukan secara online, dan tes juga dilaksanakan secara online. Sistem pembelajaran melalui daring ini dibantu dengan beberapa aplikasi, seperti Google Classroom, Google Meet, Edmudo dan Zoom.

Mencermati fakta di masyarakat saat ini yang terdampak Covid-19, banyak yang kehilangan pekerjaan dan berusaha untuk membuka lapangan pekerjaan sendiri, hal ini mempengaruhi kemampuan orang tua peserta didik secara material untuk memenuhi kebutuhan anaknya dalam hal pengadaan smartphone atau laptop dalam menunjang pembelajaran daring. Permasalahan yang terjadi tidak hanya 
dalam pengadaan sarana dan prasarana ini, namun juga pengadaan kuota (pulsa) yang membutuhkan biaya cukup tinggi terutama bagi orang tua peserta didik dari kalangan ekonomi menengah ke bawah. Tidak berhenti sampai di situ, meskipun jaringan internet dalam genggaman tangan, peserta didik menghadapi kesulitan akses jaringan internet karena tempat tinggalnya di daerah pedesaan, terpencil dan tertinggal. Kalaupun ada yang menggunakan jaringan seluler terkadang jaringan tidak stabil, karena letak geografis yang masih jauh dari jangkauan sinyal seluler. Hal ini juga menjadi permasalahan yang banyak terjadi pada peserta didik yang mengikuti pembelajaran daring, sehingga pelaksanaannya kurang efektif . (Kemdikbud, 2020).

Kendala lainnya dihadapi oleh guru dan peserta didik. Perubahan sistem pembelajaran yang terjadi secara tiba-tiba (karena pandemi covid-19) dari konvensional menjadi pembelajaran daring tentu membawa pengaruh terhadap guru untuk mempersiapkan materi, model, dan metode pembelajaran yang digunakan. Tidak jarang guru mengalami kesulitan dalam penguasaan IT sehingga proses pembelajaran tidak berlangsung secara maksimal. Dari segi peserta didik, cenderung hanya mengabsen saja dan tidak terlalu aktif terlibat dalam pembelajaran, sehingga dapat mengakibatkan penurunan motivasi belajar, konsentrasi belajar, dan berdampak pada prestasi belajar.

Hampir di semua satuan pendidikan mengalami hal serupa, begitu juga di SMA Dharma Praja Denpasar. Sekolah yang bernaung di Yayasan Dharma Praja Badung dan berlokasi di Denpasar ini, mengalami permasalahan dalam pembelajaran daring yaitu kurangnya motivasi siswa dalam belajar, penguasaan IT oleh guru khususnya guru-guru senior atau guru-guru yang terbiasa mengajar secara konvensional ketika dihadapkan dalam pembelajaran daring belum dapat dilaksanakan secara maksimal, serta orang tua siswa terutama dari ekonomi menengah ke bawah belum bisa memenuhi sarana dan prasarana dalam pelaksanaan pembelajaran daring seperti laptop, smart phone, pulsa/kuota, dan sarana prasarana lainnya yang menunjang dalam pelaksanaan pembelajaran daring serta pembayaran SPP setiap bulan belum bisa terpenuhi secara maksimal. Menariknya siswa di SMA Dharma Praja yang sebelum pembelajaran daring memiliki nilai dan pestasi akademik yang gemilang, namun setelah diberlakukannya pembelajaran daring, prestasi siswa menjadi menurun. Hal ini ditunjukkan dari nilai akademik siswa tidak sebagus atau sebaik dari pembelajaran tatap muka, serta keaktifan atau respon siswa selama pembelajaran daring kurang maksimal, bahkan untuk absen saja siswa sering terlambat bahkan lupa untuk mengabsen saat pembelajaran berlangsung padahal siswa tersebut sudah mengetahui jadwal pelajaran pada hari tersebut. Hal inilah yang menjadi alasan penulis untuk menggali penyebabnya dan menemukan solusinya.

Dari uraian di atas, dapat dipahami bahwa pembelajaran daring merupakan solusi alternatif pelaksanaan pembelajaran di masa pandemi covid-19, meskipun memunculkan sejumlah permasalahan dalam penerapannya baik dari segi guru, peserta didik, orangtua maupun institusi pendidikan. Maka dalam penelitian ini diajukan sebuah pertanyaan permasalahan penelitian, yaitu bagaimana problematika pembelajaran daring yang diterapkan di masa pandemi covid-19 dan bagimana solusi pemecahannya di SMA Dharma Praja Denpasar?

Metode yang digunakan dalam penelitian ini adalah studi kasus atau penelitian lapangan dengan menggunakan sumber data primer yang didapat melalui 
wawancara langsung dengan guru yang ada di sekolah dengan mengikuti protokol kesehatan. Menurut Ridwan (2004:102) wawancara adalah suatu cara pengumpulan data yang digunakan untuk memperoleh informasi langsung dari sumbernya. Wawancara digunakan bila ingin mengetahui hal-hal dari responden secara lebih mendalam. Teknik wawancara yang digunakan dalam penelitian ini adalah teknik wawancara mendalam (in-depth-interview) dengan informan yang sudah teridentifikasi melalui pendekatan dalam struktur sekolah terkait dengan permasalahan yang diteliti. Dalam pelaksanaan wawancara digunakan interview guide, kemudian mengoreksi pertanyaan, agar tidak menimbulkan salah tafsir, dubois (meragukan dan samar-samar) dan mungkin dapat menimbulkan reaksi negatif (Redana, 2006:168).

Pengumpulan data selanjutnya adalah dengan metode kuesioner dengan plat form google form yang ditujukan kepada para siswa yang dijadikan sampel dalam penelitian ini. Menurut Sugiyono (2001), untuk menentukan sampel yang akan digunakan dalam penelitian, terdapat berbagai teknik sampling yaitu teknik pengambilan sampel pertama adalah Probability Sampling dan kedua adalah Nonprobability Sampling. Yang termasuk ke dalam kelompok probability sampling antara lain: simple random sampling, proportionate stratified random sampling, disproportionate stratified random sampling, dan area (cluster) sampling (disebut juga dengan sampling menurut daerah). Sedangkan yang termasuk ke dalam jenis nonprobability sampling antara lain: sampling sistematis, sampling kuota, sampling aksidental, purposive sampling, sampling jenuh, dan snowball sampling.

Dalam penelitian ini teknik sampling yang digunakan yaitu probability sampling dengan teknik simple random sampling. Simple random sampling yang dikemukakan oleh Sugiyono (2017:126) adalah pengambilan anggota sampel dari populasi yang dilakukan secara acak tanpa memperhatikan strata yang ada dalam populasi tersebut. Sampel yang dipergunakan dalam penelitian ini adalah kelas 12 MIPA 4 dengan jumlah siswa laki-laki 17 orang dan siswa perempuan berjumlah 19 orang, sehingga jumlah keseluruhan sampel menjadi 36 orang.

Data yang diperoleh dari orang tua siswa, menggunakan metode kuesioner dengan plat form google form yang ditujukan kepada orangtua siswa kelas X MIPA, XI IPS 1, dan XII MIPA 3 yang dijadikan sampel dalam penelitian ini. Masingmasing tingkat/kelas diwakilkan oleh 1 kelas di semua jurusan yaitu IPA dan IPS, sehingga akan ada wakil orang tua siswa dari kelas X, XI, dan XII.

Selain itu data juga diperoleh melalui studi kepustakaan dengan menggunakan sumber data sekunder yang dikumpulkan melalui buku teks, $e$-book, peraturan perundang-undangan, website, dan sumber-sumber lain yang relevan dengan masalah penelitian. Data yang dikumpulkan, dianalisis secara kualitatif dengan model Miles and Huberman. Menurut Mile dan Huberman (dalam Sugiyono, 2010), aktivitas dalam analisis data kualitatif dilakukan secara interaktif dan terus menerus sampai tuntas yang digambarkan dalam empat langkah. Empat langkah tersebut meliputi data collecting (pengumpulan data), data reduction (reduksi data), data display (penyajian data), dan conclusion drawing/verification (penarikan kesimpulan dan verifikasi).

\section{PEMBAHASAN}

Pembelajaran daring adalah pembelajaran yang menggunakan model interaktif berbasis internet dan Learning Manajemen System (LMS). Pembelajaran 
daring merupakan program penyelenggaraan kelas pembelajaran dalam jaringan untuk menjangkau kelompok target yang masif dan luas (Bilfaqih dan Qomaruddin, 2015). Pembelajaran daring merupakan bagian dari pendidikan jarak jauh yang secara khusus menggabungkan teknologi elektronika dan teknologi berbasis internet. Pendekatan moda daring memiliki karateristrik constructivism, social constructivism, community of learners yang inklusif, pembelajaran berbasis komputer, kelas digital, interaktivitas, kemandirian, aksesibilitas, dan pengayaan (Nurhayati, 2020; Fitriyani et al, 2020; Susmiati, 2020; Hignasari, 2020).

Pembelajaran daring ini adalah solusi alternatif di tengah pandemi Covid-19 agar kegiatan belajar mengajar dapat berlangsung. Guru dapat memberikan materi pelajarannya dan peserta didik bisa belajar dari rumah. Tentunya sarana dan prasarana diperlukan untuk menunjang pembelajaran daring yang sangat bergantung pada ketersediaan teknologi informasi.

Pembelajaran daring merupakan pembelajaran yang menggunakan jaringan internet dengan aksesibilitas, konektivitas, fleksibilitas, dan kemampuan untuk memunculkan berbagai jenis interaksi pembelajaran. Penelitian yang dikakukan oleh Zhang et al., (2004) menunjukkan bahwa penggunaan internet dan teknologi multimedia mampu merombak cara penyampaian pengetahuan dan dapat menjadi alternatif pembelajaran yang dilaksanakan dalam kelas tradisional. Pembelajaran daring adalah pembelajaran yang mampu mempertemukan mahasiswa dan dosen untuk melaksanakan interaksi pembelajaran dengan bantuan internet (Kuntarto, E. (2017). Pada tataran pelaksanaanya pembelajaran daring memerlukan dukungan perangkat-perangkat mobile seperti smarphone atau telepon adroid, laptop, komputer, tablet, dan iphone yang dapat dipergunakan untuk mengakses informasi kapan saja dan dimana saja (Gikas \& Grant, 2013).

Penggunaan teknologi mobile mempunyai sumbangan besar dalam lembaga pendidikan, termasuk di dalamnya adalah pencapaian tujuan pembelajaran jarak jauh (Korucu \& Alkan, 2011). Berbagai media juga dapat digunakan untuk mendukung pelaksanaan pembelajaran secara daring. Misalnya kelas-kelas virtual menggunakan layanan Google Classroom, Edmodo, dan Schoology (Enriquez, 2014; Sicat, 2015; Iftakhar, 2016), dan applikasi pesan instan seperti WhatsApp (So, 2016). Pembelajaran secara daring bahkan dapat dilakukan melalui media social seperti Facebook dan Instagram (Kumar \& Nanda, 2018). Pembelajaran daring menghubungkan peserta didik dengan sumber belajarnya (database, pakar/instruktur, perpustakaan) yang secara fisik terpisah atau bahkan berjauhan namun dapat saling berkomunikasi, berinteraksi atau berkolaborasi (secara langsung/synchronous dan secara tidak langsung/asynchronous). Pembelajaran daring adalah bentuk pembelajaran jarak jauh yang memanfaatkan teknologi telekomunikasi dan informasi, misalnya internet, CD-ROOM (Molinda, 2005).

\subsection{Problematika Pembelajaran Daring di Masa Pandemi Covid-19}

Problematika berasal dari bahasa Inggris "problematic" yang berarti masalah atau persoalan. Problematika berasal dari kata problem yang dapat diartikan permasalahan atau masalah. Adapun masalah itu sendiri adalah suatu kendala atau persoalan yang harus dipecahkan dengan kata lain masalah merupakan kesenjangan antara kenyataan dengan suatu yang diharapkan dengan baik, agar tercapai hasil yang maksimal. Terdapat juga di dalam Kamus Besar Bahasa Indonesia kata Problematika berarti masih menimbulkan masalah; hal-hal yang masih 
menimbulkan suatu masalah yang masih belum dapat dipecahkan. Jadi, yang dimaksud dengan problematika adalah kendala atau permasalahan yang masih belum dapat dipecahkan sehingga untuk mencapai suatu tujuan menjadi terhambat dan tidak maksimal.

Peroblematika merupakan kata turunan yang terbentuk dari kata problem. Kata problem sendiri diartikan sebagai (1) persoalan, (2) masalah. Problematika merupakan sebuah istilah yang digunakan untuk menunjukkan suatu permasalahan yang harus dipecahkan (KBBI, 2008:1215). Berdasarkan definisi kedua istilah di atas, dapat ditarik benang merah bahwa sesuatu yang tengah mendapatkan problem atau masalah berarti sesuatu tersebut memerlukan pemecahan. Dalam hal ini, permasalahan tersebut sedang menggejala pada bahasa Indonesia. Dengan demikian, permasalahan yang terdapat dalam bahasa Indonesia tersebut perlu mendapatkan pemecahan atau solusi.

Dari hasil wawancara terhadap beberapa guru di SMA Dharma Praja Denpasar ditemukan beberapa kendala dalam pelaksanaan pembelajaran daring dibandingkan dengan pembelajaran tatap muka atau langsung karena beberapa alasan, yaitu :

Pertama, konten materi pembelajaran daring belum tentu dipahami oleh semua peserta didik. Hal ini dikarenakan bentuk materi tersebut dalam bentuk $e$ book atau power point yang disajikan dengan merangkum inti sari atau resume dari materi tersebut. Kemampuan siswa dalam memahami materi pembelajaran tidak komprehensif, karena para siswa menafsirkan materi tersebut dari sudut pandang mereka sendiri. Disamping itu setiap siswa memiliki tingkat pemahaman yang berbeda terhadap materi yang sama. Hal ini terbukti dari perbedaan yang signifikan terhadap materi yang telah diposting guru, banyak siswa yang menanyakan kembali mengenai materi yang telah diposting melalui chatting di whatshap atau menelpon langsung kepada guru. Tampaknya menurut hemat penulis dan berdasarkan pengalaman mengajar secara daring, sistem pemberian atau memposting materi hanya efektif untuk pemberian tugas atau kuis. Para siswa akan tekun mempelajari materi tersebut dan ada rasa "gelisah" ketika tugas belum diselesaikan dan terkirim. Berbeda halnya apabila guru memposting materi tanpa penugasan, hanya meminta untuk mempelajarinya saja, maka para siswa tidak begitu antusias dalam mempelajari materi yang diposting tersebut.

Kedua, kemampuan guru terbatas dalam penguasaan IT untuk pembelajaran daring. Tidak semua guru mampu mengoperasikan laptop, gadget, platform digital dan koneksi jaringan internet dalam pembelajaran tatap muka apalagi pembelajaran daring. Kendala ini mempengaruhi kinerja guru dalam mengajar dan memberikan materi kepada para siswa. Memang ada sebagian guru yang mampu mengoperasikan komputer, platform, aplikasi daring, dan lain-lain tetapi dalam pengoperasian masih terbatas. Mereka tidak mampu mengakses lebih jauh yang berkaitan dengan jaringan internet, menggunakan berbagai aplikasi pembelajaran, membuat media/video pembalajaran sendiri dan sebaginya.

Ketiga, keterbatasan guru dalam melakukan kontrol saat berlangsungnya pembelajaran daring. Pembelajaran daring memang adalah solusi alternatif selama pandemi Covid-19 sehingga pembelajaran dapat berlangsung, namun guru tidak bisa mengontrol para siswa secara menyeluruh, terlebih lagi saat pembelajaran menggunakan video conference, para siswa lebih memilih untuk meng-off kan kamera, dan ketika guru menanyakan mengenai kehadiran atau diskusi mengenai 
materi pelajaran, para siswa terkadang terlambat untuk merespon. Guru tidak bisa melihat sikap semua siswa saat mengikuti pembelajaran. Sosok fisik guru secara langsung atau tatap muka masih dibutuhkan dalam pembelajaran sehingga siswa lebih fokus dalam belajar.

Dari faktor peserta didik, ditemukan permasalahan atau hambatan yang dialami peserta didik selama pembelajaran daring yaitu :

Pertama, mengingat pelaksanaan pembelajaran daring sudah berlangsung hampir 1 tahun sejak pertengahan Maret 2020, menurut beberapa peserta didik terlalu lama membuat mereka malas dan bosan. Siswa di SMA Dharma Praja Denpasar, mengikuti daring selama 5 hari dari senin hingga jumat dimulai pukul 08.00 - 12.00 Wita dengan jeda istirahat 30 menit. Setiap harinya rata-rata siswa mendapatkan 3 sampai 4 mata pelajaran, masing-masing selama 60 menit. Biasanya setiap mata pelajaran memberikan tugas mandiri dan tugas kelompok kepada siswa. Siswa juga dibekali buku ajar dari sekolah sebagai bahan dan referensi dalam belajar. Situasi pembelajaran daring membuat para siswa kurang memahami materi sehingga menimbulkan rasa malas dan bosan.

Kedua, sejumlah peserta didik tinggal di wilayah yang tidak memiliki akses internet, seperti di pelosok desa dan wilayah dengan letak geografis yang tidak memungkinkan untuk jaringan internet yang stabil. Para peserta didik ini kembali ke daerah asal mereka karena orangtua mereka kehilangan pekerjaan di tempat tinggal semula karena pandemi Covid-19 ini. Kondisi ini membuat mereka tidak dapat menerima materi pelajaran bahkan tugas yang disampaikan oleh guru secara maksimal. Tidak sampai disana, peserta didik dari keluarga yang kurang mampu terkendala dalam hal pengadaan pulsa/paket internet/kuota untuk mengikuti pembelajaran daring.

Ketiga, peserta didik kurang memahami materi pembelajaran yang disampaikan oleh guru. Ini dikarenakan beberapa faktor diantaranya kemampuan peserta didik dalam mengikuti pembelajaran daring tidak komprehensif, dan tergantung dari kondisi fisik serta psikis saat pembelajaran daring berlangsung. Ketika peserta didik dalam keadaan kurang fit, tentu mempengaruhi konsentrasi dan akhirnya tidak bisa memahami materi yang diberikan. Dan ketika peserta didik dalam keadaan gelisah, cemas, kesal, dan emosi lainnya sudah tentu membuatnya sulit menerima materi pembelajaran.

Dalam pembelajaran daring dimasa pandemi covid 19 ini, orang tua merupakan salah satu orang yang berpengaruh atas keberlangsungan kegiatan belajar mengajar, karena orang tualah yang mampu mengawasi, mengontrol dan membantu anak dalam menyelesaikan segala tugas dan pembelajaran yang diberikan oleh guru selama diberlakukannya Study Frome Home/daring ini. Sehingga orang tua memiliki peran penting dalam pendidikan anaknya, baik itu edukasi mengenai bahaya pandemi Covid-19 maupun mata pelajaran yang diajarkan disekolah. Dengan begitu kegiatan belajar mengajar selama pandemi covid-19 masih bisa terus berlangsung meski dilakukan secara daring.

Keadaan orang tua peserta didik, turut serta mempengaruhi pelaksanaan pembelajaran daring, misalnya latar belakang sosial ekonomi orang tua peserta didik. Saat pembelajaran daring berlangsung, mereka rata-rata bekerja di luar rumah, baik bekerja di sektor pemerintah, swasta maupun wiraswasta, hingga nyaris tidak bisa memantau dan mendampingi anak-anaknya belajar, apalagi membimbing langsung dan memecahkan kesulitan yang mereka hadapi saat belajar. Sisi lain, 
sebagian orangtua mengeluh karena pembelajaran online menambah biaya pengeluaran. Karena itu mereka berharap pemerintah segara mengubah kebijakannya ke belajar tatap muka sebagaimana biasa meskipun dijadwalkan dengan sistem block/shif.

\subsection{Solusi Pemecahan Pembelajaran Daring di Masa Pandemi Covid-19}

Proses pembelajaran daring ini sebenarnya bisa dilaksanakan dengan baik asalkan sarana dan prasaranan terpenuhi dan merata. Dengan banyaknya kendala yang dihadapi, menjadi tantangan tersendiri bagi guru. Guru di sini sangat berpengaruh sekali dalam proses pembelajaran daring. Bagaimana guru menyikapi pembelajaran daring ini dan mengatasi berbagai kendala yang dihadapi. Guru bisa mengatasi berbagai kendala yang dihadapi dalam pembelajaran daring ini dengan memaksimalkan sumber daya yang ada dan membuat rancangan pembelajaran yang mudah diakses oleh siswa supaya siswa mudah dalam belajar dan memahami materi yang diberikan guru.

Bagi guru dalam mengatasi kendala pembelajaran daring yaitu dengan menyiapkan materi pembelajaran semenarik mungkin dalam bentuk power point lengkap dengan ilustrasi gambar dan video yang terkait dengan materi tersebut sehingga membuat peserta didik lebih fokus dan tertarik untuk belajar. Disamping itu guru dapat membuat video pembelajaran yang menarik sehingga materi tersebut dirasakan lebih "hidup" oleh peserta didik. Dalam hal penguasaan IT, guru dapat menggunakan aplikasi yang sederhana misalnya whatshapp untuk mengirim materi pembelajaran baik disajikan dalam bentuk power point, audio dan video. Namun, sedikit demi sedikit guru harus meningkatkan kompetensi IT-nya, antara lain dengan mengikuti workshop terkait, bertanya kepada guru-guru lain yang mempunyai kemampuan lebih di bidang IT (Puspitasari dalam Kemdikbud, 2020).

Guru dapat memperkaya materi dan kemampuan mengajarnya dari youtobe yang menyajikan aplikasi pembelajaran dan langkah-langkah penggunaannya, serta bagaimana memproduksi video pembelajaran, sehingga dalam menyampaikan materi tidak monoton dan siswapun lebih tertarik untuk mengikuti pembelajaran. Bagi peserta didik yang sering alpa atau tidak pernah mengikuti pembelajaran daring tanpa kabar berita, dapat diatasi dengan menghubungi langsung melalui telepon atau menghubungi orang tuanya, dan dapat juga home visit dengan menaati protokol kesehatan. Solusi lain, guru bersama guru BK mencari tau apakah yang menjadi kendala siswa tersebut tidak pernah mengikuti daring dan mencari solusi bersama orang tuanya. Bila kendala memang anaknya malas, maka guru BK akan meminta pada orangtuanya agar dapat mendampingi pelaksanaan Belajar Dari Rumah (BDR) anaknya (Arianty dalam Kemdikbud, 2020).

Nampaknya ada kesalahtafsiran orang tua peserta didik dan bahkan guru mengenai "belajar dari rumah selama masa pandemi Covid19". Sejak diberlakukan "belajar dari rumah" pada pertengahan Maret lalu, banyak orang tua kerepotan karena harus mendampingi belajar anak di rumah. Pihak sekolah melaksanakan proses pembelajaran yang berpindah dari kelas ke rumah. Materi dan tugas diberikan melalui daring atau secara online, melalui berbagai platform yang disediakan pemerintah maupun swasta. Padahal, maksud pemerintah mengenai "belajar dari rumah selama masa pandemi Covid-19 tidak seperti itu. Plt Dirjen PAUD dan Dikmas, Harris Iskandar, mengatakan, dalam proses pembelajaran dari rumah, seharusnya guru dan orang tua diharapkan dapat 
mewujudkan pendidikan yang bermakna, tidak hanya berfokus pada capaian akademik atau kognitif. Dijelaskan Harris, konsep pembelajaran yang tidak hanya fokus pada akademik atau kognitif itu sesuai dengan model penilaian yang akan menggantikan ujian nasional (UN), yaitu Asesmen Kompetensi dan Survei Karakter. Harris menuturkan, Asesmen Kompetensi dan Survei Karakter lebih menitikberatkan pada penalaran dan bukan capaian pemahaman materi mata pelajaran.

Selanjutnya bagi peserta didik, rasa malas dan bosan dapat diatasi dengan membuat suasana belajar di rumah senyaman mungkin sesuai kebutuhan. Misalnya mengikuti pembelajaran daring dalam posisi duduk tidak berbaring, selalu sedia tumbler air minum, sedikit snack favorit yang ada di sekitar meja belajar, penerangan ruangan belajar yang cukup, suasana nyaman atau tidak berisik, suhu ruangan sejuk dan memastikan fisik dalam keadaan sehat, bugar, semangat, serta siap untuk belajar. Kendala jaringan internet dan keterbatasan kuota adalah masalah umum yang hampir sebagian besar dialami oleh peserta didik, hal ini bisa diatasi dengan menggunakan paket internet khusus untuk pelajar dengan segala kemudahan yang didapat sehingga peserta didik dapat mengikuti pembelajaran daring dengan baik. Jaringan internet yang terkadang kurang stabil dapat diatasi dengan pergi ke tempat yang sekiranya terdapat jaringan internet. Jika hal ini sulit, maka dapat menghubungi guru yang mengajar agar diberikan permakluman untuk belum bisa mengikuti daring dan meminta kepada guru agar membantu mengirimkan materinya, dan jika ada hal-hal yang kurang jelas dapat menghubungi guru yang mengajar. Susani (dalam Kemdikbud, 2020) peserta didik yang mengalami permasalahan koneksi internet dapat diatasi dengan thethering ke anggota keluarga lainnya atau menghemat dengan cara connect saat dibutuhkan saja. Penulis berpendapat bahwa dapat juga diatasi dengan mengikuti program pendidikan lewat siaran televisi yang diselenggarakan oleh Kementerian Pendidikan dan Kebudayaan bekerjasama dengan TVRI dalam rangka memfasilitasi pendidikan di masa pandemi Covid-19 di Indonesia.

Solusi permasalahan dari faktor orang tua yakni dengan melakukan komunikasi via telpon kepada anak-anaknya yang sedang daring di rumah untuk memastikan bahwa anak telah mengikuti pembelajaran daring. Orang tua/wali peserta didik diharapkan meluangkan waktu untuk memperhatikan anak-anaknya. Orang tua/wali dapat menghubungi wali kelas untuk mendapatkan informasi terkait prestasi belajar serta keterlibatan anak-anaknya dalam bentuk kehadiran selama pembelajaran daring. Pengampu mata pelajaran menghubungi langsung nomor handphone peserta didik untuk menanyakan sebab-sebab tidak mengerjakan tugas yang diberikan; meminta bantuan kepada guru BK untuk memotivasi peserta didik dalam belajar (Susilowati dalam Kemdikbud, 2020). Solusi untuk permasalahan bertambahnya pengeluaran dalam penyediaan pulsa/kuota, dapat diatasi dengan membeli paket internet belajar dan dipergunakan seperlunya. Disamping itu orang tua dapat mengijinkan anaknya untuk belajar di tempat-tempat umum yang ada fasilitas wifi seperti balai pertemuan, mini market, gedung serba guna, dan lain-lain yang tentunya mengikuti protokol kesehatan.

\section{SIMPULAN}

Pelaksanaan pembelajaran daring yang merupakan pembelajaran jarak jauh di masa pandemi covid-19 memiliki beragam problematika yang dialami guru, 
peserta didik, dan orangtua. Permasalahan dari guru berupa lemahnya penguasaan IT dan terbatasnya akses pengawasan peserta didik, dari peserta didik berupa kekurangaktifan mengikuti pembelajaran, keterbatasan fasilitas pendukung dan akses jaringan internet, sementara dari orangtua berupa keterbatasan waktu dalam mendampingi anaknya di saat pembelajaran daring. Beragam permasalahan tersebut dapat diatasi dengan meningkatkan kompetensi penguasaan IT, pengawasan intensif dengan melibatkan peran orangtua, dan memberikan penugasan secara manual.

Dalam proses pembelajaran daring guru bisa membuat banyak sekali variasi model pembelajaran. Walaupun prakteknya saat melakukan meeting melalui zoom atau google meet, guru akan lebih dominan daripada siswa, guru bisa menyisipkan kegiatan yang menarik buat siswa seperti ice breaking. Dalam pembawaannya guru harus terlihat gembira, membuat suasana yang ceria dan pintar-pintar dalam mengawasi siswa yang kadang ada siswa tidak termotivasi ikut belajar daring. Jika pembelajarannya melalui aplikasi whatsapp, guru jangan hanya memberi tugas terus, tetapi juga memberikan materi untuk bisa digunakan siswa sebagai bahan belajar. Keberhasilan guru dalam melakukan pembelajaran daring pada situasi pandemi Covid-19 ini adalah kemampuan guru dalam berinovasi merancang, dan meramu materi, metode pembelajaran, dan aplikasi apa yang sesuai dengan materi dan metode. Kreatifitas merupakan kunci sukses dari seorang guru untuk dapat memotivasi siswanya tetap semangat dalam belajar secara daring (online) dan tidak menjadi beban psikis.

Di samping itu, kesuksesan pembelajaran daring selama masa Covid-19 ini tergantung pada kedisiplinan semua pihak. Oleh karena itu, pihak sekolah/madrasah di sini perlu membuat skema dengan menyusun manajemen yang baik dalam mengatur sistem pembelajaran daring. Hal ini dilakukan dengan membuat jadwal yang sistematis, terstruktur dan simpel untuk memudahkan komunikasi orangtua dengan sekolah agar putra-putrinya yang belajar di rumah dapat terpantau secara efektif. Dengan demikian, pembelajaran daring sebagai solusi yang efektif dalam pembelajaran di rumah guna memutus mata rantai penyebaran Covid-19, physical distancing (menjaga jarak aman) juga menjadi pertimbangan dipilihnya pembelajaran tersebut. Kerjasama yang baik antara guru, siswa, orangtua siswa dan pihak sekolah/madrasah menjadi faktor penentu agar pembelajaran daring lebih efektif.

Dari hasil penelitian ini, saran yang dapat diberikan yaitu (1) bagi guru dan siswa, penelitian ini dapat dijadikan pedoman untuk mengetahui problematika pembelajaran daring dan solusinya yangsebagian besar dari guru dan siswa mengalaminya. (2) dalam pembelajaran daring terkait pandemi Covid-19, hendaknya guru mencari solusi yang inovatif dalam penyampaian materi pembelajaran sehingga siswa dapat mengikuti dengan baik serta mengurnagi kejenuhan siswa dalam belajar.

\section{DAFTAR PUSTAKA}

Arikunto, Suharsimi. (2013). Prosedur Penelitian: Suatu Pendekatan Praktik. Jakarta: Rineka Cipta

Arianty, Dini. (2020). Belajar dari Covid-19 dalam Pengalaman Baik Mengajar dari Rumah 
di Masa Pandemi Covid-19 Mata Pelajaran Matematika (e-book). Jakarta: Kemdikbud.

Keputusan Bersama Menteri Pendidikan dan Kebudayaan, Menteri Agama, Menteri Kesehatan dan Menteri Dalam Negeri No. 01/KB/2021, No. 516 Tahun 2020, No. HK.03.01/Menkes/363/2020, dan No. 440-882 tentang Panduan Penyelenggaraan Pembelajaran pada Tahun Ajaran 2020/2021 dan Tahun Akademik 2020/2021 di masa Covid-19

Sugiyono. (2012). Metode Penelitian Kuantitatif Kualitatif dan R\&D. Alfabeta.

Susilowati. (2020). Pengalaman Baik Pembelajaran di Rumah Mata Pelajaran Bahasa Indonesia di SMPN 6 Semarang dalam Pengalaman Baik Mengajar dari Rumah di Masa Pandemi Covid-19 Mata Pelajaran Bahasa Indonesia ( $e$ book). Jakarta: Kemdikbud.

Surya, Hendra. 2004. Kiat Mengatasi Kesulitan Belajar. Jakarta: PT Gramedia.

Suryabrata, Sumadi. 2004. Psikologi Pendidikan. Jakarta Utara: PT.Raja Grafindo Persada.

Undang-undang Dasar 1945 Pasal 31 ayat (1)

Undang-undang Nomor 20 tahun 2003 tentang Sistem Pendidikan Nasional 